\title{
The detection of SARS-CoV-2 RNA in indoor air of dental clinics during the COVID-19 pandemic
}

\author{
Shahriyar Bazzazpour ${ }^{1}$ - Masoumeh Rahmatinia ${ }^{1}$ - Seyed Reza Mohebbi $^{2} \cdot$ Mostafa Hadei $^{3} \cdot$ Abbas Shahsavani $^{4,1}$. \\ Philip K. Hopke ${ }^{5,6}$ • Behzad Houshmand $^{7}$. Alireza Raeisi ${ }^{8}$. Ahmad Jonidi Jafari ${ }^{9}$ - Maryam Yarahmadi ${ }^{10}$. \\ Mohsen Farhadi ${ }^{10}$. Vajihe Hasanzadeh ${ }^{1}$. Majid Kermani ${ }^{9} \cdot$ Mohmmad Hossien Vaziri $^{11} \cdot$ Mohammad Tanhaei $^{12}$. \\ Mohammad Reza Zali ${ }^{2} \cdot$ Mohammad Reza Alipour $^{1}$
}

Received: 3 May 2021 / Accepted: 20 July 2021 / Published online: 3 August 2021

(C) The Author(s), under exclusive licence to Springer-Verlag GmbH Germany, part of Springer Nature 2021

\begin{abstract}
In the indoor environment of dental clinics, dental personnel and patients are exposed to a risk of infection because of the transmission of SARS-CoV-2 via particles or droplets. This study investigated the presence of SARS-CoV-2 RNA in indoor air of dental clinics in Tehran, Iran. Air sampling was done $(n=36)$ collecting particulate samples on PTFE filters at flow rates of 30 to $58 \mathrm{~L} / \mathrm{min}$. The samples were analyzed with novel coronavirus nucleic acid diagnostic real-time PCR kits. Only 13 out of 36 samples were positive for SARS-CoV-2 RNA. Logistic regression showed that sampling site's volume, $\mathrm{PM}_{2.5}$ concentration, number of people, and number of active patient treatment units were significantly positively related with the presence of SARS-CoV-2 RNA. Thus, strategies to control the spread of COVID-19 should include reducing the number of infected people in dental clinics, adding filtration systems, and/or improving ventilation conditions.
\end{abstract}

Keywords COVID-19 $\cdot$ SARS-CoV-2 $\cdot$ Indoor air $\cdot$ Dental clinics $\cdot$ Airborne transmission $\cdot \mathrm{PM}_{2.5}$

\section{Introduction}

In December 2019, the severe acute respiratory syndrome coronavirus (SARS-CoV-2) emerged in Wuhan City, Hubei (China), and spread quickly throughout the world. On March 11, 2020, the World Health Organization (WHO) announced a pandemic

\section{Responsible Editor: Lotfi Aleya}

Abbas Shahsavani ashahsavani@gmail.com

1 Department of Environmental Health Engineering, School of Public Health and Safety, Shahid Beheshti University of Medical Sciences, Tehran, Iran

2 Gastroenterology and Liver Diseases Research Center, Research Institute for Gastroenterology and Liver Diseases, Shahid Beheshti University of Medical Sciences, Tehran, Iran

3 Department of Environmental Health Engineering, School of Public Health, Tehran University of Medical Sciences, Tehran, Iran

4 Air Quality Health and Climate Change Research Center, Shahid Beheshti University of Medical Sciences, Tehran, Iran

5 Department of Public Health Sciences, University of Rochester School of Medicine and Dentistry, Rochester, NY 14642, USA
(FERNANDES et al. 2020; IZZETTI et al. 2020; MUNIYAPPA and GUBBI 2020; WANG et al. 2021). In Iran, the first officially known case of COVID-19 was identified on February 19, 2020, by the Iranian Ministry of Health and Medical Education (MOHME). After this date, the number of COVID-19 cases increased day by day according to MOHME data. The virus

6 Center for Air Resources Engineering and Science, Clarkson University, Potsdam, NY 13699, USA

7 Department of Periodontics, School of Dentistry, Shahid Beheshti University of Medical Sciences, Tehran, Iran

8 Department of Internal Medicine, School of Medicine, Shiraz University of Medical Sciences, Shiraz, Iran

9 Research Center for Environmental Health Technology, Iran University of Medical Sciences, Tehran, Iran

10 Environmental and Occupational Health Center, Ministry of Health and Medical Education, Tehran, Iran

11 Workplace Health Promotion Research Center, Shahid Beheshti University of Medical Sciences, Tehran, Iran

12 Foodborne and Waterborne Diseases Research Center, Research Institute for Gastroenterology and Liver Diseases, Shahid Beheshti University of Medical Sciences, Tehran, Iran 
rapidly spread to other parts of Iran, and by March 5, 2020, all 31 provinces had significant numbers of infected individuals (RAOOFI et al. 2020).

The most common clinical manifestations of COVID-19 include sore throat, fever, cough, shortness of breath, and fatigue. According to previous studies, the incubation period of the virus varies between 1 and 14 days, and asymptomatic infections have been observed (HU et al. 2020; ISAIFAN 2020; KLOMPAS 2020; NOBEL et al. 2020). The primary transmission routes of COVID-19 virus are airborne and direct contact. Airborne infection occurs via droplets and particles emitted from infected individuals by speech, coughing, sneezing, and breathing. Direct contact infection occurs via contact with contaminated surfaces including people followed by touching of the eyes, mouth, or nose. Saliva can also play a role in transmission of infection via the airborne and direct contact routes (JARVIS 2020). During the COVID-19 pandemic, both dentists and dental assistants are at high risk of being infected in oral dental treatment practice due to their exposure to bacteria, viruses, and fungi resident in respiratory tract and the oral cavity. Furthermore, the high-speed gas and running water of dental handpieces generate high particle and droplet concentrations that incorporate the patient's saliva or blood. These fluids contaminate the clinic space and the surfaces of diverse dental devices, increasing the risk of infection for clinic personnel and subsequent dental patients. To stop crossinfection and the outbreak of the epidemic, most dental clinics around the world suspended dental and oral healthcare during a lockdown period (COULTHARD 2020). The American Dental Association (Corman et al.) stated that dental emergencies are life-threatening and need urgent therapy to stop tissue bleeding, reduce major infections, or intense pain. Thus, the entire dental team is at risk of acquiring COVID-19 through local transmission in the dental clinic. The closure of dental clinics at least for emergencies was not suggested. Some studies have reported negative results with respect to the presence of this virus in the indoor air of hospitals (FARIDI et al. 2020; MASOUMBEIGI et al. 2020). However, SARS-CoV-2 RNA was detected in the indoor air of different hospital wards (LIU et al. 2020; RAZZINI et al. 2020). Thus, concern about dentistry practice-driven coronavirus transmission has been broadly known worldwide. To our knowledge, no studies have been reported to date on the presence of SARS-CoV-2 in the indoor air of dental clinics. Therefore, the present research evaluated the contamination of the air by SARSCoV-2 RNA in dentistry clinics during COVID-19 pandemic outbreak in Tehran, Iran.

\section{Material and methods}

\section{Study area and air sampling}

We conducted the present study between August and December 2020 in the dental clinics of Shahid Beheshti
University of Medical Sciences, Tehran, Iran. Tehran, with a population of around 9 million, is the most populous city in Iran and is the nation's capital. In total, 36 air samples were collected from seven clinics in the city. For all of the sampling sites, an AV1000 high-volume air sampler (China) was employed to collect fine particulate matter $\left(\mathrm{PM}_{2.5}\right)$ samples on polytetrafluoroethylene filters $(\mathrm{PTFE}$, diameter $=9 \mathrm{~cm}$, pore size $=0.2 \mu \mathrm{m})$. The sampling flow rates and sampling durations were $30-58 \mathrm{~L} / \mathrm{min}$ and $1-2 \mathrm{~h}$, respectively. The sampler height above the floor was between 1 and $2 \mathrm{~m}$, and the approximate distance of 0.8 to $2 \mathrm{~m}$ was maintained with the individuals in the room. During the sampling process, several characteristics of sites including surface area, height, temperature, relative humidity, overall site volume, number of active treatment units, number of people, and ventilation conditions (type of ventilation, number of windows, number of ventilators, flow velocity of ventilator's outlet, and air change per hour) were measured and reported. Also, air changes per hour parameter for the mechanical ventilators were estimated by the following equation:

$A C H=\frac{Q}{V}=\frac{\sum_{\mathrm{i}=0}^{\mathrm{n}}\left(A_{\mathrm{i}} \times u_{\mathrm{i}}\right)}{V}$

where

$A C H$ is air change per hour, $Q$ is total outlet flow from mechanical ventilators $\left(\mathrm{m}^{3} / \mathrm{h}\right), V$ is site volume $\left(\mathrm{m}^{3}\right), A_{\mathrm{i}}$ is area of ventilation outlet channel $\left(\mathrm{m}^{2}\right), u_{\mathrm{i}}$ is outlet flow velocity of mechanical ventilator $(\mathrm{m} / \mathrm{s})(\mathrm{CHINN}$ and SEHULSTER 2003).

\section{Viral RNA concentrations}

After the air samples were collected, they were transferred to the Virology Laboratory (RIGLD, Shahid Beheshti University of Medical Sciences) under cool conditions (temperature $4^{\circ} \mathrm{C}$ ). Immediately in the laboratory, the filters were placed in 50-mL centrifuge tubes by adding $20 \mathrm{~mL}$ of Tris-glycinebeef extract buffer (TGBE, 100-mM Tris, 50-mM glycine, 3\% $(\mathrm{w} / \mathrm{v})$ beef extract, $\mathrm{pH}=9.5)$ followed by shaking at room temperature for $20 \mathrm{~min}$. Then, the filters came out of the tubes, and $2.5 \%(\mathrm{w} / \mathrm{v}) \mathrm{NaCl}$ and $12.5 \%(\mathrm{w} / \mathrm{v})$ PEG-6000 at final concentration were added (approximately $25 \mathrm{~mL}$ ). The solution was mixed at $120 \mathrm{rpm}$ by shaker for $2 \mathrm{~h}$ at $4^{\circ} \mathrm{C}$ and, after that, centrifuged for $30 \mathrm{~min}$ at $11,000 \mathrm{~g}$ (ZUO et al. 2013). The pellet was suspended in $200 \mu \mathrm{L}$ of PBS $(\mathrm{pH}=7.2)$ and stored at $-80{ }^{\circ} \mathrm{C}$ until subsequent analyses.

To estimate the performance of the virus extraction method, a virus should be selected that had a similar structure and similar target tissue. Also, the virus must have been from the same family as SARS-CoV-2. For this purpose, infectious bronchitis virus (IBV), a member of the family Coronavirus and belonging to Gammacoronavirus, was selected. The diluted IBV virus was inoculated on the surface of filter. Then, 
filter was placed in a biosafety chamber for $2 \mathrm{~h}$, and concentration process was conducted. After that, $20 \mu \mathrm{L}$ of the vaccine was added to $120 \mu \mathrm{L}$ of water and was extracted, and an RT-qPCR test was performed on the target RNA. The tests demonstrated a recovery percentage of about $25 \%$ in comparison with first value (HADEI et al. 2021).

\section{Extraction of viral RNA}

In the second concentration phase, $140 \mu \mathrm{L}$ of final solution were obtained. QIAamp RNA Mini Kit (Qiagen, Germany) was used for extraction of viral nucleic acids from the final solution. Finally, final volume of $60 \mu \mathrm{L}$ was produced, and the isolated nucleic acids were placed at $-20{ }^{\circ} \mathrm{C}$ chamber until detection test.

\section{Detection of SARS-CoV-2 RNA}

The presence of SARS-CoV-2 RNA was investigated by the novel coronavirus nucleic acid diagnostic real-time PCR kit (Sansure Biotech, China) based on the manufacturer's protocol. Sequences of nucleocapsid protein N and ORF1ab genes were chosen as the target zone and detected using a RotorGene Q instrument (Qiagen, Germany).

\section{Quality assurance. Quality control (QA. QC)}

In this study, to ensure the elimination of false-positive and false-negative results, quality control of the RT-PCR tests occurred using positive and negative control samples.

\section{Statistical analyses}

Descriptive statistics of characteristics of sampler and sampling sites were investigated. Descriptive statistics of the quantitative variables (sampling site's volume $\left(\mathrm{m}^{3}\right)$, number of people, number of units, temperature, relative humidity, $\mathrm{PM}_{2.5}$ concentration, number of windows, and number of mechanical ventilators) and qualitative variables (type of ventilation and presence of SARS-CoV-2) were calculated. Also, the characteristics of sampling sites with presence/absence of SARS-CoV-2 were compared. Normality of data and equity of variances were tested using Shapiro-Wilk and Levene's test, respectively. If datasets passed both tests, a parametric test (independent $t$-test) was conducted; otherwise, nonparametric analysis (Mann-Whitney U test) was performed.

Logistic regression was used to explore the effects of the parameters on the presence of SARS-CoV-2. These parameters were used as continuous independent variables, and the presence/absence of SARS-CoV-2 was entered to the model as a binary variable of zero and one. The associations between the variables were expressed as odds ratios (ORs) with $95 \%$ confidence intervals (CIs). The modeling was performed using R programming software v. 3.6.3.

\section{Results and discussion}

The details of sampling sites such as the sampling site's volume, surface area, number of people, number of units, temperature, relative humidity, $\mathrm{PM}_{2.5}$ concentration, number of windows, and ventilation conditions (type of ventilation, number of windows, number of ventilators, flow velocity of ventilator's outlet, and air change per hour) are presented in Table 1 . The sampled air volume at the various sites varied from 2900 to $5972 \mathrm{~L}$. Table 2 summarizes the results of descriptive statistics for sampling sites and environmental conditions. Overall, the average ( \pm 1 standard deviation) relative humidity and temperature during sampling periods were 45.6 (7.4\%) and $28.5( \pm 2.6)^{\circ} \mathrm{C}$, respectively. Thirty-six air samples were collected from the dental clinics. About $36 \%$ of the air samples were positive for SARS-CoV-2 RNA occurrence. These results are similar to previous studies that reported that SARS-CoV-2 was present in indoor air (JIN et al. 2021; LIU et al. 2020; RAZZINI et al. 2020). These results support the hypothesis of airborne transmission of SARS-CoV-2 in the indoor environment. A study in Iran examined the airborne potential of SARS-CoV-2 and stated there was no airborne transmission potential (MASOUMBEIGI et al. 2020). The effects of the sampling site's volume, distance between the individuals present, number of people present during sampling, number of active treatment units, number of ventilators, air temperature, relative humidity, $\mathrm{PM}_{2.5}$, windows, speed of exhaust air, and air change per hour on the presence of SARSCoV-2 RNA in the air are provided in Table 3 . The number of people, number of dental treatment units, $\mathrm{PM}_{2.5}$ concentration, and sampling site volume were positively related with the presence of SARS-Cov-2 RNA. All of these relationships were statistically significant. Air temperature, speed of exhaust air, and air changes per hour were negatively associated to SARS-CoV-2 RNA presence (Table 4). These results indicate that the increase in speed of exhaust air and number of air changes per hour reduced the presence of SARS-CoV-2 in indoor locations below the detection limits. Our results are consistent with other studies (HADEI et al. 2021; RAZZINI et al. 2020). They reported that the presence of SARS-CoV-2 in air of hospitals and public places could be associated to the number of people. More people lead to higher concentrations of SARS-CoV-2 RNA. Thus, reducing the number of people allowed to be present at any given time and number of active treatment units can likely reduce the transmission of the virus in dental clinics. Previous studies have reported that durability of SARS-CoV-2 decreases with temperature reduction in different environments and may elucidate the negative relate with temperature (CHENG et al. 2020; YAO et al. 2020). In 


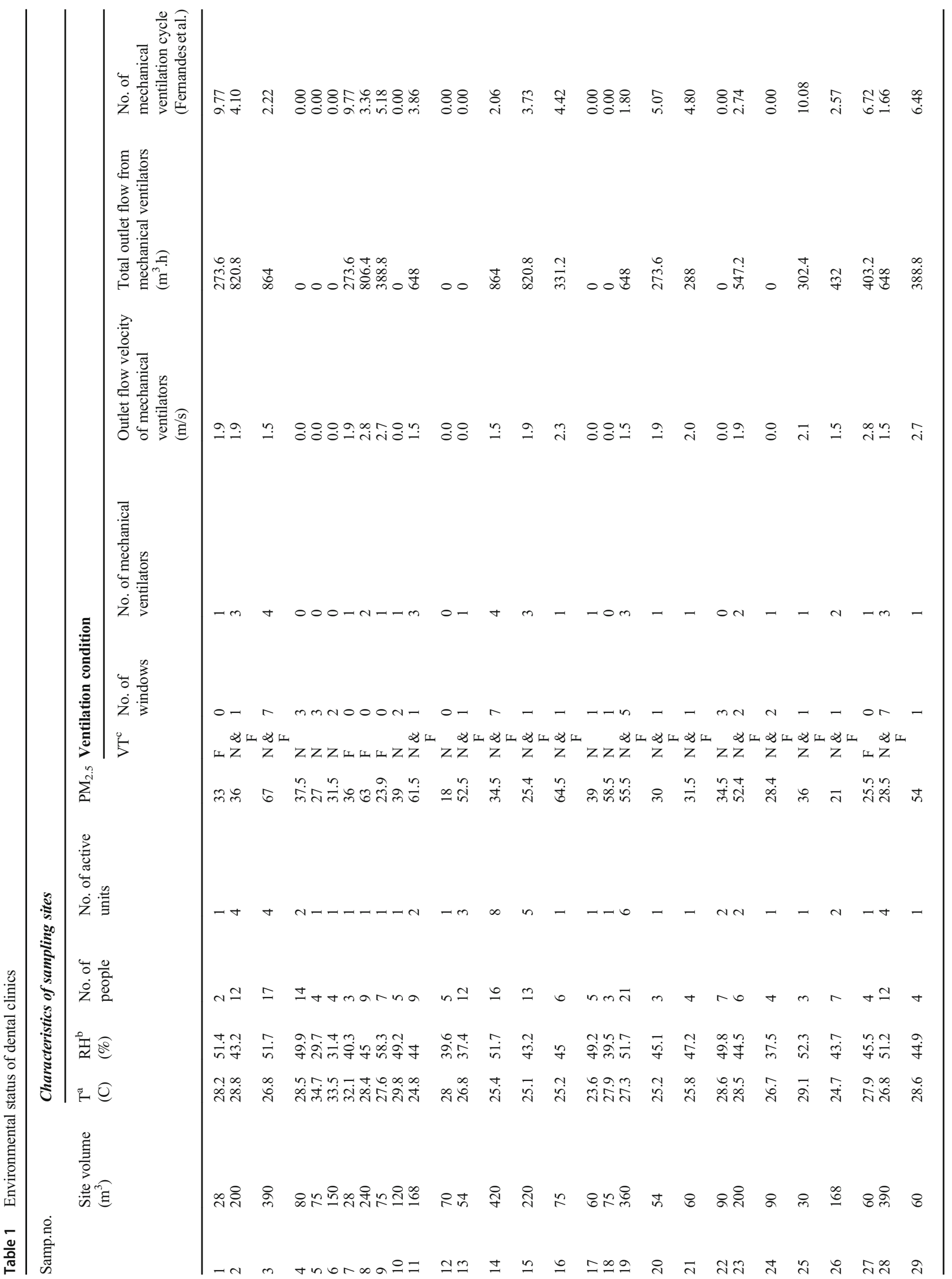




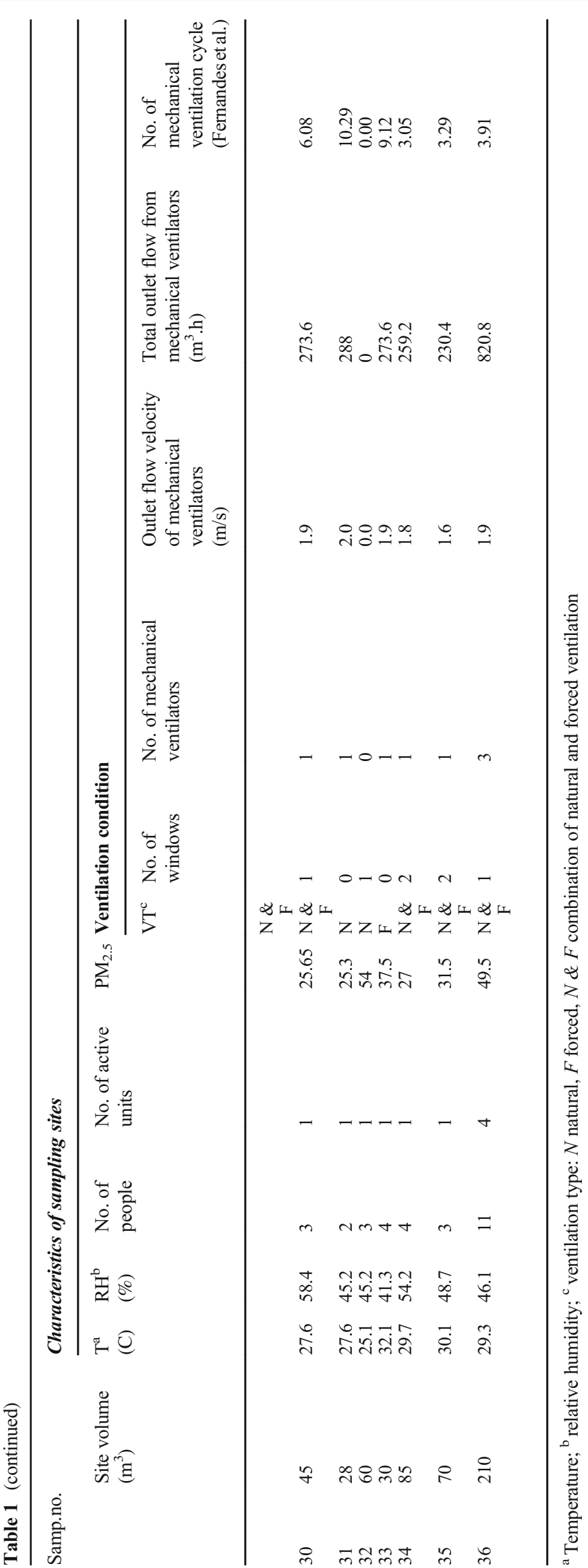


Table 2 Summary statistics of sampling sites and environmental conditions

\begin{tabular}{|c|c|c|c|c|c|c|c|c|c|c|}
\hline \multirow[t]{2}{*}{ Parameter } & \multicolumn{5}{|c|}{ Negative results } & \multicolumn{5}{|c|}{ Positive results } \\
\hline & Mean & Median & $\begin{array}{l}\text { Std. } \\
\text { deviation }\end{array}$ & Maximum & Minimum & Mean & Median & $\begin{array}{l}\text { Std. } \\
\text { deviation }\end{array}$ & Maximum & Minimum \\
\hline $\begin{array}{l}\text { Distance between sampler and } \\
\text { individuals (m) }\end{array}$ & 1.20 & 1.00 & 0.35 & 2.00 & 0.80 & 1.31 & 1.00 & 0.44 & 2.00 & 0.80 \\
\hline Site's volume $\left(\mathrm{m}^{3}\right)$ & 85.57 & 70.00 & 78.81 & 390.00 & 28.00 & 203.85 & 200.00 & 122.67 & 420.00 & 54.00 \\
\hline Temperature $\left({ }^{\circ} \mathrm{C}\right)$ & 28.55 & 28.00 & 2.56 & 34.70 & 25.10 & 26.87 & 26.80 & 2.01 & 29.80 & 23.60 \\
\hline Relative humidity (\%) & 45.63 & 45.20 & 7.40 & 58.40 & 29.70 & 46.35 & 45.20 & 4.20 & 51.70 & 37.40 \\
\hline No. of people & 5.13 & 4.00 & 3.39 & 14.00 & 2.00 & 10.23 & 9.00 & 5.33 & 21.00 & 3.00 \\
\hline No. of active dental units & 1.39 & 1.00 & 1.03 & 5.00 & 1.00 & 3.00 & 2.00 & 2.16 & 8.00 & 1.00 \\
\hline $\mathrm{PM}_{2.5}\left(\mu \mathrm{g} \mathrm{m}^{3}\right)$ & 33.49 & 31.50 & 11.30 & 64.50 & 18.00 & 48.07 & 52.40 & 13.29 & 67.00 & 21.00 \\
\hline No. of windows & 1.39 & 1.00 & 1.59 & 7.00 & 0.00 & 2.31 & 1.00 & 2.39 & 7.00 & 0.00 \\
\hline No. of mechanical ventilator & 0.91 & 1.00 & 0.79 & 3.00 & 0.00 & 2.23 & 2.00 & 1.24 & 4.00 & 0.00 \\
\hline $\begin{array}{l}\text { Outlet flow velocity of mechanical } \\
\text { ventilators }(\mathrm{m} \mathrm{s})\end{array}$ & 1.43 & 1.90 & 1.02 & 2.80 & 0.00 & 1.23 & 1.50 & 0.92 & 2.80 & 0.00 \\
\hline Air change per hour (Fernandes et al.) & 4.33 & 4.42 & 3.74 & 10.29 & 0.00 & 2.05 & 2.22 & 1.59 & 4.10 & 0.00 \\
\hline
\end{tabular}

our research, there was a positive relation between the presence of SARS-CoV-2 and $\mathrm{PM}_{2.5}$ concentration. These results have demonstrated that SARS-CoV-2 may have airborne transmission potential in dental clinics (KAYALAR et al. 2021). Also, airborne transmission of SARS-CoV-2 was previously examined by Setti et al. in air of industrial area of Bergamo (Italy) (SETTI et al. 2020). They stated that it could be concluded that the infection was transmitted via $\mathrm{PM}_{2.5}$ particles. Although the airborne transmission of SARS-CoV2 has been evaluated, it was pointed out this virus had not airborne potential (FARIDI et al. 2020). Different analysis and sampling methods can cause these contradictions. The sampled air volume is a crucial agent for these studies, because collecting a low sampled air volume (low sampling duration or low sampling flow rate) could generate a falsenegative result (HADEI et al. 2021). Van Doremalen et al. (2020) reported that SARS-CoV-2 survived in aerosols at least for $3 \mathrm{~h}$ under laboratory conditions (VAN DOREMALEN et al. 2020). These results indicated that the virus could be transmitted through aerosol processes in such environments (SANTARPIA et al. 2020). Clearly some aerosol-generating practices are related with a significant enhancement in the risk of disease transmission (LUO et al. 2021). However, it can be concluded that ventilation is an efficient technology for reducing exposures in dental clinics. WHO has recommended that a ventilation rate of at least 288 $\mathrm{m}^{3} \mathrm{~h}^{-1}$ per person is an efficient method for control of airborne transmission virus such as influenza and SARS in healthcare settings. Some variables such as $\mathrm{PM}_{2.5}$ concentration, temperature, and relative humidity affect the stability and presence of SARS-CoV-2 in indoor air. Therefore, controlling these parameters in optimal values can play an important role in preventing virus spreading (BABOLI et al. 2021). In addition, although research on COVID-19 transmission is not yet definitive, precautionary measures should be used including efficient ventilation, indoor air purifiers, and avoidance of air recirculation without adequate filtration in healthcare setting (ZHAO et al. 2020).

In the current study, there were several limitations. Because of the requirements of each site, the maximum distance maintained between the sampler and individuals was $2 \mathrm{~m}$. Under these circumstances, it will be difficult to say with certainty that the virus is being transmitted over longer distances. However, the statistical relationship found between ventilation conditions, $\mathrm{PM}_{2.5}$, and the presence of the viral RNA suggests its airborne nature. This study did not investigate the viability and infectivity of the virus. RT-PCR is a reliable tool for detecting the SARS-CoV-2 RNA in respiratory secretions (CORMAN et al. 2020), but it is important to note that PCR does not necessarily determine the presence of viable, infective virus (OTTER et al. 2016). Future study must focus on viability conditions of SARS-CoV-2 in dental practices.

\section{Conclusions}

This research provides the first report of the presence of SARS-CoV-2 RNA in the indoor air of dental clinics. In this study, 36 samples were analyzed for the presence of SARSCoV-2 RNA in the indoor air of dental clinic (Tehran, Iran). The results of the research have identified the presence of SARS-CoV-2 viral RNA in about $36 \%$ of these samples. Thus, these results provide an alert with respect to the airborne transmission of SARS-CoV-2 in dental practices. Positive 
Table 3 Presence of SARS-CoV2 in indoor air samples of dental clinics

\begin{tabular}{|c|c|c|c|c|c|c|}
\hline \multirow{2}{*}{$\begin{array}{l}\text { Samp. } \\
\text { no. }\end{array}$} & \multirow{2}{*}{$\begin{array}{l}\text { Sampling } \\
\text { duration }(\mathrm{h})\end{array}$} & \multicolumn{5}{|c|}{ Characteristics of sampler } \\
\hline & & 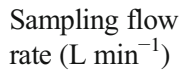 & $\begin{array}{l}\text { Sampling } \\
\text { volume }\left(\mathrm{m}^{3}\right)\end{array}$ & $\begin{array}{l}\text { Height of } \\
\text { sampler (m) }\end{array}$ & $\begin{array}{l}\text { Distance from } \\
\text { human individuals }\end{array}$ & $\begin{array}{l}\text { SARS- } \\
\text { CoV-2 }\end{array}$ \\
\hline
\end{tabular}

(m)

\begin{tabular}{|c|c|c|c|c|c|c|}
\hline 1 & 1.00 & 50 & 2.972 & 1.4 & 1.0 & Negative \\
\hline 2 & 1.00 & 50 & 2.973 & 2.0 & 1.0 & Positive \\
\hline 3 & 1.00 & 50 & 2.971 & 1.4 & 1.0 & Positive \\
\hline 4 & 1.00 & 50 & 2.973 & 1.6 & 0.8 & Negative \\
\hline 5 & 1.00 & 58 & 3.483 & 1.0 & 1.2 & Negative \\
\hline 6 & 1.00 & 58 & 3.448 & 1.0 & 1.2 & Negative \\
\hline 7 & 1.50 & 35 & 3.146 & 1.2 & 0.8 & Negative \\
\hline 8 & 1.00 & 49 & 2.912 & 1.6 & 2.0 & Positive \\
\hline 9 & 1.00 & 50 & 2.972 & 1.6 & 1.5 & Negative \\
\hline 10 & 1.00 & 50 & 2.974 & 1.4 & 1.5 & Positive \\
\hline 11 & 2.00 & 35 & 4.101 & 1.5 & 1 & Positive \\
\hline 12 & 1.00 & 55 & 3.287 & 1.4 & 1 & Negative \\
\hline 13 & 1.50 & 40 & 3.577 & 1.6 & 2 & Positive \\
\hline 14 & 2.00 & 50 & 5.897 & 1.4 & 1 & Positive \\
\hline 15 & 2.00 & 50 & 5.971 & 2 & 1 & Negative \\
\hline 16 & 2.00 & 40 & 4.768 & 1.6 & 1 & Negative \\
\hline 17 & 2.00 & 50 & 5.972 & 1.4 & 1 & Positive \\
\hline 18 & 1.00 & 50 & 2.981 & 1.2 & 1.5 & Negative \\
\hline 19 & 2.00 & 45 & 5.391 & 1.0 & 1.5 & Positive \\
\hline 20 & 1.00 & 49 & 2.901 & 1.6 & 2 & Negative \\
\hline 21 & 1.50 & 50 & 4.462 & 1.4 & 1 & Negative \\
\hline 22 & 1.00 & 50 & 2.987 & 1.0 & 1 & Negative \\
\hline 23 & 2.00 & 30 & 3.551 & 1.0 & 2 & Positive \\
\hline 24 & 1.00 & 55 & 3.279 & 1.0 & 1.5 & Negative \\
\hline 25 & 1.50 & 40 & 3.582 & 1.2 & 0.8 & Negative \\
\hline 26 & 1.50 & 45 & 4.036 & 1.6 & 0.8 & Positive \\
\hline 27 & 1.00 & 50 & 2.978 & 1.4 & 1.0 & Negative \\
\hline 28 & 2.00 & 30 & 3.588 & 1.4 & 1.0 & Negative \\
\hline 29 & 1.50 & 55 & 4.943 & 1.2 & 1.5 & Negative \\
\hline 30 & 1.50 & 35 & 3.145 & 1.2 & 1.0 & Negative \\
\hline 31 & 1.00 & 50 & 2.987 & 2.0 & 2.0 & Negative \\
\hline 32 & 1.00 & 50 & 2.984 & 1.0 & 1.0 & Positive \\
\hline 33 & 2.00 & 30 & 3.542 & 1.4 & 1.0 & Negative \\
\hline 34 & 1.00 & 50 & 2.981 & 1.0 & 1.4 & Negative \\
\hline 35 & 1.00 & 50 & 2.921 & 1.0 & 1.5 & Negative \\
\hline 36 & 2.00 & 45 & 5.372 & 1.6 & 1.2 & Positive \\
\hline
\end{tabular}

Table 4 Results of the logistic regression models for the effects of different parameters on the presence of SARS-CoV-2 in air

\begin{tabular}{lll}
\hline Independent variables & Odds ratio $(95 \% \mathrm{CI})$ & $p$ value \\
\hline Sampling site's volume & $1.02(1.01,1.03)$ & 0.01 \\
Distance & $2.05(0.33,13.08)$ & 0.43 \\
Temperature & $0.71(0.46,0.98)$ & 0.06 \\
Relative humidity & $1.02(0.91,1.14)$ & 0.74 \\
$\mathrm{PM}_{2.5}$ & $1.09(1.03,1.17)$ & 0.01 \\
$\mathrm{Number}$ of people & $1.31(1.09,1.64)$ & 0.01 \\
Number of units & $2.02(1.21,4.09)$ & 0.02 \\
Windows & $1.28(0.89,1.93)$ & 0.19 \\
Number of ventilators & $1.22(0.89,1.71)$ & 0.22 \\
Speed of exhaust air & $0.81(0.39,1.64)$ & 0.55 \\
Air change per hour & $0.77(0.56,0.98)$ & 0.06 \\
\hline
\end{tabular}

relationships between SARS-CoV-2 RNA and site volume, $\mathrm{PM}_{2.5}$, number of people, and number of dental treatment units were obtained. These findings suggest the need to control the occupancy of these spaces (number of individuals in certain environments) especially in hospitals and dental clinics. Rigorous strategies need to be implemented to diminish the risk of infection for patients and healthcare professionals working in dental clinics through improved ventilation and/or effective air cleaning systems. Also, there is a need to reassess the commonly used recommendations for ventilation rates in closed environments relative to that provided by the WHO to reduce the potential for infections in locations where active generation processes are ongoing.

Acknowledgements The authors wish to extend their thanks to dentists and personnel of Shahid Beheshti University of Medical Sciences. 
Author contribution Shahriyar Bazzazpour: methodology, writingoriginal draft preparation. Masoumeh Rahmatinia: writing — original draft preparation. Seyed Reza Mohebbi: methodology, writing - review and editing, validation, and formal analysis. Mostafa Hadei: conceptualization, methodology, writing - review and editing, and formal analysis. Abbas Shahsavani: conceptualization, methodology, writing-review and editing, supervision, and resources. Philip K. Hopke: conceptualization, methodology, writing - review and editing. Behzad Houshmand: methodology, resources, writing - review and editing. Alireza Raeisi: methodology, resources, and writing-review and editing. Ahmad Jonidi Jafari: conceptualization, methodology, and writing - review and editing. Maryam Yarahmadi: investigation and methodology. Mohsen Farhadi: resources and writing-review and editing. Vajihe Hasanzadeh: investigation and resources and writing - review and editing. Majid Kermani: methodology and writing - review and editing. Mohmmad Hossien Vaziri: methodology, resources, and review and editing. Mohammad Tanhaei: methodology, writing - review and editing, and validation. Mohammad Reza Zali: conceptualization, resources, writing - review and editing. Mohammadreza Alipour: investigation, methodology, and writing - review and editing.

Funding This study was financially supported by the Shahid Beheshti University of Medical Sciences (grant number \#24241).

Data availability The datasets used and/or analyzed during this study are included in this published article.

\section{Declarations}

Ethics approval The approval number of ethics of the present study was "IR.SBMU.PHNS.REC.1399.075."

Consent for publication Not applicable

Competing interests The authors declare no competing interests.

\section{References}

BABOLI Z, NEISI N, BABAEI AA, AHMADI M, SOROOSHIAN A, BIRGANI YT, GOUDARZI G (2021) On the airborne transmission of SARS-CoV-2 and relationship with indoor conditions at a hospital. Atmos Environ 261:118563. https://doi.org/10.1016/j.atmosenv. 2021.118563

CHENG VCC, WONG S-C, CHEN JHK, YIP CCY, CHUANG VWM, TSANG OTY, SRIDHAR S, CHAN JFW, HO P-L, YUEN K-Y (2020) Escalating infection control response to the rapidly evolving epidemiology of the coronavirus disease 2019 (COVID-19) due to SARS-CoV-2 in Hong Kong. Infect Control Hosp Epidemiol 41: 493-498. https://doi.org/10.1017/ice.2020.58

Chinn RY, Sehulster L (2003) Guidelines for environmental infection control in healthcare facilities; recommendations of CDC and Healthcare Infection Control Practices Advisory Committee (HICPAC). CDC and HICPAC, Atlanta, GA

CORMAN VM, LANDT O, KAISER M, MOLENKAMP R, MEIJER A, CHU DK, BLEICKER T, BRÜNINK S, SCHNEIDER J, SCHMIDT ML (2020) Detection of 2019 novel coronavirus (2019-nCoV) by real-time RT-PCR. Euro Surveill 25:2000045. https://doi.org/10.2807/1560-7917.ES.2020.25.3.2000045

COULTHARD P (2020) Dentistry and coronavirus (COVID-19)-moral decision-making. Br Dent J 228:503-505. https://doi.org/10.1038/ s41415-020-1482-1
FARIDI S, NIAZI S, SADEGHI K, NADDAFI K, YAVARIAN J, SHAMSIPOUR M, JANDAGHI NZS, SADEGHNIIAT K, NABIZADEH R, YUNESIAN M (2020) A field indoor air measurement of SARS-CoV-2 in the patient rooms of the largest hospital in Iran. Sci Total Environ 725:138401. https://doi.org/10.1016/j. scitotenv.2020.138401

FERNANDES L, PACHECO V, BORGES L, ATHWAL H, DE PAULA EDUARDO F, BEZINELLI L, CORREA L, JIMENEZ M, DAME-TEIXEIRA N, LOMBAERT I (2020) Saliva in the diagnosis of COVID-19: a review and new research directions. J Dent Res 99:1435-1443. https://doi.org/10.1177/0022034520960070

HADEI M, MOHEBBI SR, HOPKE PK, SHAHSAVANI A, BAZZAZPOUR S, ALIPOUR M, JAFARI AJ, BANDPEY AM, ZALI A, YARAHMADI M (2021) Presence of SARS-CoV-2 in the air of public places and transportation. Atmos Pollut Res 12:302306. https://doi.org/10.1016/j.apr.2020.12.016

HU Z, SONG C, XU C, JIN G, CHEN Y, XU X, MA H, CHEN W, LIN Y, ZHENG Y (2020) Clinical characteristics of 24 asymptomatic infections with COVID-19 screened among close contacts in Nanjing, China. Sci China Life Sci 63:706-711. https://doi.org/10. 1007/s11427-020-1661-4

ISAIFAN R (2020) The dramatic impact of coronavirus outbreak on air quality: has it saved as much as it has killed so far? Glob J Environ Sci Manag 6:275-288. https://doi.org/10.22034/gjesm.2020.03.01

IZZETTI R, NISI M, GABRIELE M, GRAZIANI F (2020) COVID-19 transmission in dental practice: brief review of preventive measures in Italy. J Dent Res 99:1030-1038. https://doi.org/10.1177/ 0022034520920580

JARVIS MC (2020) Aerosol transmission of SARS-CoV-2: physical principles and implications. Front Public Health 8:813. https://doi. org/10.3389/fpubh.2020.590041

JIN T, LI J, YANG J, LI J, HONG F, LONG H, DENG Q, QIN Y, JIANG J, ZHOU X (2021) SARS-CoV-2 presented in the air of an intensive care unit (ICU). Sustain Cities Soc 65:102446. https:// doi.org/10.1016/j.scs.2020.102446

Kayalar Ö et al (2021) Existence of SARS-CoV-2 RNA on ambient particulate matter samples: A nationwide study in Turkey. Sci Total Environ 789:147976. https://doi.org/10.1016/j.scitotenv. 2021.147976

Klompas M (2020) Coronavirus disease 2019 (COVID-19): protecting hospitals from the invisible. Ann Intern Med 172(9):619-620. https://doi.org/10.7326/M20-0751

LIU Y, NING Z, CHEN Y, GUO M, LIU Y, GALI NK, SUN L, DUAN Y, CAI J, WESTERDAHL D (2020) Aerodynamic analysis of SARS-CoV-2 in two Wuhan hospitals. Nature 582:557-560. https://doi.org/10.1038/s41586-020-2271-3

LUO W, LEE GHM, NALABOTHU P, KUMAR H (2021) Paediatric dental care during and post-COVID-19 era: changes and challenges ahead. Pediatr Dent J 31:33-42. https://doi.org/10.1016/j.pdj.2021. 01.003

MASOUMBEIGI H, GHANIZADEH G, ARFAEI RY, HEYDARI S, GOODARZI H, SARI RD, TAT M (2020) Investigation of hospital indoor air quality for the presence of SARS-Cov-2. J Environ Health Sci Eng 18:1259-1263. https://doi.org/10.1007/s40201-020-005433

MUNIYAPPA R, GUBBI S (2020) COVID-19 pandemic, coronaviruses, and diabetes mellitus. Am J Physiol Endocrinol Metab 318:E736-E741. https://doi.org/10.1152/ajpendo.00124. 2020

NOBEL YR, PHIPPS M, ZUCKER J, LEBWOHL B, WANG TC, SOBIESZCZYK ME, FREEDBERG DE (2020) Gastrointestinal symptoms and coronavirus disease 2019: a case-control study from the United States. Gastroenterology 159:373-375.e2. https://doi. org/10.1053/j.gastro.2020.04.017

OTTER J, DONSKEY C, YEZLI S, DOUTHWAITE S, GOLDENBERG S, WEBER D (2016) Transmission of SARS and 
MERS coronaviruses and influenza virus in healthcare settings: the possible role of dry surface contamination. J Hosp Infect 92:235250. https://doi.org/10.1016/j.jhin.2015.08.027

RAOOFI A, TAKIAN A, SARI AA, OLYAEEMANESH A, HAGHIGHI H, AARABI M (2020) COVID-19 pandemic and comparative health policy learning in Iran. Arch Iran Med 23:220-234. https://doi.org/10.34172/aim.2020.02

RAZZINI K, CASTRICA M, MENCHETTI L, MAGGI L, NEGRONI L, ORFEO NV, PIZZOCCHERI A, STOCCO M, MUTTINI S, BALZARETTI CM (2020) SARS-CoV-2 RNA detection in the air and on surfaces in the COVID-19 ward of a hospital in Milan, Italy. Sci Total Environ 742:140540. https://doi.org/10.1016/j. scitotenv.2020.140540

Santarpia JL, Rivera DN, Herrera VL, Morwitzer MJ, Creager HM, Santarpia GW, Crown KK, Brett-Major DM, Schnaubelt ER, Broadhurst MJ, Lawler JV, Reid SP, Lowe JJ (2020) Aerosol and surface contamination of SARS-CoV-2 observed in quarantine and isolation care. Sci Rep 10(1):12732. https://doi.org/10.1038/ s41598-020-69286-3

SETTI L, PASSARINI F, DE GENNARO G, BARBIERI P, PERRONE MG, BORELLI M, PALMISANI J, DI GILIO A, TORBOLI V, FONTANA F, CLEMENTE L, PALLAVICINI A, RUSCIO M, PISCITELLI P, MIANI A (2020) SARS-Cov-2RNA found on particulate matter of Bergamo in Northern Italy: first evidence. Environ Res 188:109754. https://doi.org/10.1016/j.envres.2020.109754
VAN DOREMALEN N, BUSHMAKER T, MORRIS DH, HOLBROOK MG, GAMBLE A, WILLIAMSON BN, TAMIN A, HARCOURT JL, THORNBURG NJ, GERBER SI, LLOYDSMITH JO, DE WIT E, MUNSTER VJ (2020) Aerosol and surface stability of SARS-CoV-2 as compared with SARS-CoV-1. N Engl J Med 382:1564-1567. https://doi.org/10.1056/NEJMc2004973

WANG C, MIAO L, WANG Z, XIONG Y, JIAO Y, LIU H (2021) Emergency management in a dental clinic during the coronavirus disease 2019 (COVID-19) epidemic in Beijing. Int Dent J 71:32-39. https://doi.org/10.1111/idj.12609

YAO M, ZHANG L, MA J, ZHOU L (2020) On airborne transmission and control of SARS-Cov-2. Sci Total Environ 731:139178. https:// doi.org/10.1016/j.scitotenv.2020.139178

ZHAO B, LIU Y, CHEN C (2020) Air purifiers: a supplementary measure to remove airborne SARS-CoV-2. Build Environ 177:106918. https://doi.org/10.1016/j.buildenv.2020.106918

ZUO Z, DE ABIN M, CHANDER Y, KUEHN TH, GOYAL SM, PUI DY (2013) Comparison of spike and aerosol challenge tests for the recovery of viable influenza virus from non-woven fabrics. Influenza Other Respir Viruses 7:637-644. https://doi.org/10. 1111/irv.12095

Publisher's note Springer Nature remains neutral with regard to jurisdictional claims in published maps and institutional affiliations. 